\title{
МИСТЕЦЬКЕ ШОУ: МАНІПУЛЯЦІЯ МИСТЕЦТВОМ ЧИ МИСТЕЦТВО МАНІПУЛЯЦІї?
}

У статті розглянуто екранне мистецьке шоу у контексті естетичних та комунікативних пріоритетів. Проаналізовано науковий дискурс понять «шоу», «шоу-технологї̈,, «шоуїзація». Визначено високу міру маніпулятивності сучасного шоу.

Ключові слова: шоу, шоу-технології, шоуїзація, мистецьке шоу.

The article discusses screen art shows in the context of aesthetic and communicative priorities. The scientific discourse of the concepts of «show», «show technology», «showization» is analyzed. The high degree of manipulability of a modern show is determined.

Keywords: show, show technology, showization, art show.

В статье рассмотрено экранное художественное шоу в контексте эстетических и коммуникативных приоритетов. Проанализирован научный дискурс понятий «шоу», «шоу-технологии», «шоуизачия». Определена высокая степень манипулятивности современного шоу.

Ключевые слова: шоу, шоу-технологии, шоуизация, художественное шоу.

Слово «шоу» вже давно і впевнено утвердилося в сучасному медіапросторі та нашому побуті. У науковому дискурсі використовуються не лише сталі вислови на кшталт шоу-бізнесу, а й відносно нові, зокрема шоу-індустрія, шоу-політика, шоу-дискурс, шоу-иивілізація, шоу-контент, шоу-дидактика. Усі ці «подвоєння» передбачають активне впровадження шоу-технологій (ще одне, ключове «подвоєння») у відповідні соціокультурні сфери.

Засадничими чинниками цих шоу-технологій слід відзначити ігрове начало, наявність ролей-амплуа, змагальний характер розвитку події, конкурентну комунікацію, інтерактивність, кліповість, переважання емойіо над раиіо. Усе це в комплексі обумовлює найголовнішу, як на мене, особливість шоу, його причинно-наслідкову квінтесенцію, його водночас вихідну позицію, основний метод впливу та фінальний результат маніпулятивність. Спробуємо розглянути в цьому контексті сучасне мистецьке шоу та визначити його естетичні та комунікативні пріоритети.

Досліджуючи шоу як соціокультурну форму, українські й зарубіжні вчені (К. Акопян, Е. Бурдіна, Н. Дубовик, І. Коротаєва, Ю. Романенко,
А. Скрипка, В. Стаметов, О. Тимохович та ін.) відштовхуються передусім від поняття «видовище». Справді, у постмодерному суспільстві спектаклю (влучно названому Гі Ернестом Дебором ще 1967-го у книжці «La Société du spectacle») саме видовищність, демонстративність, образна опосередкованість починають визначати комунікативну орієнтацію не лише мистецтва, а й політики, бізнесу, громадського життя та побуту — культури загалом. Природно, що провідною ознакою суспільства спектаклю став видовищецентризм (термін російського культуролога Миколи Хренова). Його думку поділяе Володимир Мартинов: «на зміну літературоцентризму приходить якийсь новий “центризм”, який поки що за відсутністю кращого в робочому порядку можна визначити як “видовищецентризм”, або як “шоуцентризм”» $[9$, 33].

Отже, більшість дослідників простежують історичний шлях шоу від стародавніх видовищ, а його біологічні передумови, на думку В. Стаметова, зводяться до «соціального імпринтингу»вродженої схильності до копіювання поведінки, що іiі транслює лідер $[14,165]$. Погодьмося, що традиційні видовища завжди демонстрували фор- 
му наймасовішої комунікації, а отже напряму пов'язані із масовою свідомістю учасника-глядача.

У сучасних умовах під феноменом шоу вчені пропонують розуміти:

- «масове театралізоване дійство, що побудоване за ігровим принципом і має видовищний характер» [5, 224];

- «одну 3 найяскравіших форм сучасної розважальної культури, що містить основні відмінні особливості постмодернізму, зокрема синтез, монтаж, фрагментарність та амбівалентність» [8];

- «форму псевдокомунікативного спілкування, що має характер масового видовища, технологічно орієнтовану на закріплення в аудиторії потрібних організаторам вражень та оцінок, зокрема й на невербальному рівні» $[14,170]$;

- «сучасну культурну форму, що є символічним художнім витвором, підпорядкованим певному жанру, основу якого становить поєднання засад відтворення традиційних видовищних форм із сучасними технологічними можливостями візуалізації з урахуванням суспільної сфери, в межах якої відбуватиметься трансляція результатів цього втілення» [11, 7]; «конкретну подію, яка відбувається в просторі та часі, представляє поєднання принципів створення символічних художніх витворів, $з$ одного боку, та комерційно-вигідних проєктів - 3 іншого, як правило, реалізується на засадах масової культури, має яскраво виражений видовищний та розважальний характер, а також латентну спонукальну спрямованість» [11, 7]; «потужну комунікативну технологію» $[11,1]$; «соціокомунікативний феномен» $[11,1]$;

- «феномен культури, в якому провідну роль грає зовнішнє, формальне, зв'язки якого з сутнісним, глибинним якщо і не відкидаються, то не можуть розглядатися як ті, що мають істотне значення» $[1,18]$.

Цікавий приклад диференціації шоу і видовища висловлює I. Коротаєва, називаючи шоу «згущеним видовищем», що презентує граничний максимум різноманітності та виразності. Дослідниця доходить висновку, що «шоу, з'єднуючись з будь-якими формами побутування явищ мистецтва, привносячи в них усі свої характеристики (передусім особливу видовищність), сприяє перетворенню цих явищ у продукцію масової культури» [8].

Як бачимо, дослідники обирають різні критерії для визначення поняття «шоу»: характерні ознаки будь-якого видовища взагалі, постмодерну специфіку, комунікативну складову, соціокультурні особливості, онтологічні виміри. Така панорама підходів свідчить не лише про масштабність та багатофункціональність означеного феномена, а й про його глибоке проникнення в усі сфери життя суспільства. Це відбувається завдяки вже згаданим вище шоу-технологіям.

Безперечно, провідними каналами розповсюдження шоу-технологій $є$ телебачення та інтернет, позаяк саме вони демонструють найвищий ступінь візуалізації i, так би мовити, видовищезації ретрансльованої інформації. Навіть ті мистецькі шоу, що знімаються у сценічних (концертних) умовах і вже за походженням є видовищними, у своєму екранному втіленні набувають нових потужних рис інтерактивності, підкресленої виразності, розцвіченої барвистості, шику-блиску. А. Скрипка влучно зазначає, що шоу-технології «поступово перетворюються на основну форму подання інформації та засіб конструювання подій різного рівня значущості» $[11,1]$.

Шоу-технології перетворюють видовище та середовище, в якому воно функціонує, на особливий світ. Дослідниця С. Колтишева, розглядаючи метафоричну модель «Шоу-бізнес це релігія» й аналізуючи іiі вербальний корпус у медіа-ресурcax, доводить, що в ній, як і в реальній картині світу, «присутні боги і демони, праведники і грішники, божа благодать і покарання за гріхи» [7, 84]. Бог Рейтинг і Богиня прайм-тайму, свій Олімп та зірковий пантеон, ідоли та ідеали, гуру та пророки, ритуали та забобони - усім цим наповнений шоу-дискурс, посилюючи емоційно-експресивний вплив на глядача і тим самим актуалізуючи ідеологічну та маніпулятивну функції шоу $[7,88]$.

Розглядаючи комунікаційні особливості шоу-технологій, варто звернути увагу на поняття псевдокомунікаиіï, уживане В. Стаметовим. Псевдокомунікацію автор протиставляє духовній (i, власне, істинній, на думку автора) комунікації. Духовна комунікація відзначається продуктивним спілкуванням двох рівноправних партнерів у стані спільного «психічного резонансу» за відсутності лідерства та агресії. Натомість псевдокомунікація є спілкуванням нерівних, де лідер досягає власних цілей (чи цілей замовника), нав'язуючи свої правила щодо певної діяльності та способи поведінки, формуючи у співрозмовника потрібні йому уявлення. I саме таке «буття соціальних псевдокомунікацій» - «масштабне, невикорінне, сповнене потужних протиріч» — $€$ фундаментальною характеристикою шоу [13].

Ще одна шоу-технологія, що дає змогу маніпулювати увагою глядача, передбачає тимчасове (але воно може бути й досить тривалим) відвертання уваги глядача від стрижневої, магістральної 
теми завдяки зміщенню акцентів у бік другорядних елементів, явищ, подій. Така кліповість шоу визначається його структурною фрагментарністю, своєрідним «нагнітанням новизни» звідусіль, калейдоскопічністю продукованих вражень, постійним порушенням «непорушних» правил. Спостерігається цікавий парадокс: аби утримати увагу глядача, шоу має повсякчас його відволікати від стрижневої лінії на додаткові, паралельні рівні, але робити це з підвищеною мірою експресивності. Таку експресивність забезпечують медіаресурси, використовуючи максимальну міру візуалізації, епатажності, сенсаційності, симулятивності. Фактично створюється медійний ажіотаж, бум, інформаційна лихоманка навколо осіб чи подій, що самі по собі не привертають до себе уваги, зчиняється галас «на порожньому місці», «буря в склянці води» або, як кажуть у народі, «діла на копійку, а балачок на карбованець». У цьому контексті вся палітра виражальних засобів мистецького шоу спрямовується на те, аби провокувати глядачів, підвищувати їхній емоційне тло, відволікати їх від зосереджено-аналітичного оцінювання, натомість підживлюючи спонтанно-експресивні прояви. За таких умов «уявна або реальна участь в шоу стає звичкою швидше, ніж людина встигає прийняти екзистенційне рішення 3 цього приводу» $[12,20]$.

Успішне, популярне шоу стає таким завдяки тому, що виявляє у глядача незадоволені потреби - у коханні, повазі, самоповазі, залученні до соціокультурної активності, усвідомленні належності до певної соціальної групи, самовираженні, відпочинку і розвагах, емоційній релаксації і задовольняє їх. Дослідниця О. Тимохович влучно зазначає, що «кожний складовий елемент видовищного дійства має спрямовуватися на глядача, організовувати його увагу, утворювати враження. Потрібно, аби кожен компонент видовищного дійства (тобто мовлення, пластика, речове середовище, динамічні, механічні ефекти), що впливає на глядача, був розрахований з максимальним урахуванням глядацького сприйняття» $[15,11]$.

У своєму найвищому прояві така «орієнтація на глядача» перетворюється на потужну шоу-технологію якорування. Цей психологічний термін означає свідому або частіше несвідому установку, що насаджується людині (власне якір), фіксуючи в ній міцний умовно-рефлекторний зв'язок. $\mathrm{y}$ мистецькому шоу найчастіше це примусове запам'ятовування певних образів чи символів, повторення яких викликатиме у людини конкретну емоційну реакцію, потрібну маніпуляторові.
Зрозуміло, що таке насадження глядачеві програми-якоря уможливлює в подальшому керування ним. Використовуючи потужні методи психологічного впливу на аудиторію шоу, зокрема навіювання, імітування, тиск під маскою переконливості, шоу-технології стають у такий спосіб вагомим засобом формування світогляду та світосприйняття глядача, важелем маніпулювання його свідомістю та прихильністю.

Весь комплекс шоу-технологій (розглянутих вище та інших) у дії можна представити як умовну схему процесу, провідною ознакою якого буде посилення маніпулятивності на кожному наступному етапі: інформація про - популяризація реклама - пропаганда - інформаційний терор.

Глобальне проникнення шоу-технологій чи не в усі сфери суспільного життя, що ми спостерігаємо сьогодні, уможливлює науковий дискурс навколо явища шоуїзаиії. Так, Н. Дубовик доходить висновку, що шоу виходить за рамки телебачення та індустрії розваг, стаючи сучасною карнавалізованою формою культури, що дає авторові можливість говорити про явище «шоутизації» [5, 224].

А. Скрипка наголошує, що шоу стає універсальною комунікативною практикою сучасного суспільства, елементи якої (апеляція до чуттєвого рівня сприйняття, видовищність, епатажність, симулятивність, спрощення смислів, висока технологічність, адаптивність до соціальних запитів) проникають в усі сфери суспільного життя $[11,8]$.

Д. Сжов теж вважає шоуїзацію «об’єктивно існуючою реальністю, що має цивілізаційну природу» $[6,132]$.

Е. Бурдіна вживає поняття «шоуїзація» синонімічно з виразами «розвага заради розваги» [3, 15], «спосіб шокувати глядача» [3, 65], «яскрава форма без змісту» $[3,78]$, що, на нашу думку, є не надто точним і дещо обмеженим. Утім, погоджуємося з авторкою, що поняття шоуїзації «поєднує і розважальний аспект, і розрахованість на сенсаційність, і акцентування уваги на "обгортці” повідомлення. Термін використовується здебільшого медіакритиками й науковцями для позначення негативних тенденцій у журналістиці (порожня видовищність, прийоми заради прийомів, обман глядацьких очікувань, маніпулятивність тощо)» $[3,76]$.

К. Акопян під терміном «шоуїзація» розуміс відносно самостійний процес поширення шоу як специфічного соціокультурного феномена. Учений засмучується, що сьогодні на шоу перетворюється те, що таким не може бути апріорі: виступи артистів академічного мистецтва, презентації 
наукових праць та отримання грантів, телевізійні трансляції богослужінь, політичні акції; і гірко жартує, що процес шоуїзації чудово римується 3 процесами цивілізації та глобалізації $[1,19]$.

Своє тлумачення терміна «шоуїзація» дає Ю. Романенко, дослівно переводячи це слово як «показуха». На думку автора, шоуїзація - це установка сучасної цивілізації, обумовлена тотальним поширенням засобів масової інформації та комунікації, яка виражається у маніпуляції зором натовпу, постійному прагненні виставити будь-які факти і явища напоказ, задоволенні гіпертрофованої психологічної потреби у видовищах. Шоуїзація виявляється в експансії візуальної культури, налаштованої на ураження уяви обивателя через безперервне відстеження і демонстрацію у режимі non-stop екстраординарних подій, використовуючи дві основні форми шоуїзаційної подачі матеріалу - сенсацію та ексклюзив. Шоуїзація сама фактично і $є$ інформаційним тероризуванням - екстремальним способом реалізації можливостей засобів масової комунікації. Гаслом шоуїзації може бути рядок з видатної пісні Фредді Мерк’юрі «Show must go on»: шоу має тривати за будь-яких обставин [10].

А суспільство з цього приводу, - дивується Ю. Афанасьєв, - не надто непокоїться. «Його (суспільство. - K. С.), видається, вже привчили, що, перефразовуючи напівзабутого класика, для нас найважливішим 3 мистецтв $є$ шоу. Шоуїзація культурного життя стає тотальною, і суспільство 3 якоюсь дивною байдужістю спостерігає, не опирається тому, що його перетворюють на римський натовп часів Нерона, всі потреби якого формулювалися двома словами: хліба і видовищ. Утім, закони культурного життя свідчать про те, що якщо гарно оброблене поле, яке ще нещодавно було засаджене культурними рослинами, хоча б рік не культивувати, воно заросте бур'яном. А бур'ян вже не в змозі усвідомити, що він не $\epsilon$ культурною рослиною, та це йому і байдуже. Зате він усвідомлює себе господарем на цьому полі, а поодинокі де-не-де вцілілі культурні рослини видаються йому дивними маргіналами, потреби яких (культурні потреби) не обов'язково задовольняти» $[2,172]$.

Швидкі темпи шоуїзації та потужна активізація щодо виробництва шоу пояснюються двома взаємообумовленими факторами: $з$ одного боку, шоу-технології спрямовані на маніпулювання глядачами та здійснення певних змін у свідомості суб'єктів комунікації (через «підсадження» глядача на те чи інше телешоу), з другого — самі глядачі у певний спосіб маніпулюють виробниками телепродукту (своїм інтересом, жвавою інтерактивною участю, високим рейтингом перегляду), стимулюючи продовження улюблених шоу в наступних сезонах та створення нових подібних форм. Така взаємообумовленість призводить до того, що розважально-гедоністичні функції мистецького шоу поступово втрачають свою першість, а на авансцену виходить керування свідомістю глядача і різновекторне маніпулювання його інтересами і оцінками, емоціями і настроєм, та загалом - суспільною позицією.

Отже, погоджуся з думкою В. Гопка, що одне з головних завдань шоуїзації - розважати і відвертати увагу, викликаючи в суспільстві почуття хронічного переживання свята $[4,14]$. I додам: а наслідки такого переживання (які, ймовірно, будуть і негативними) ліквідуватимуться за допомогою нового шоу. Чи зможе людина вистрибнути 3 цієї show-must-go-on'ної зацикленості? Чи захоче? Сьогоденний рівень маніпулятивності шоу не надто обнадіює.

\section{Джерела та література}

1. Акопян К. З. Шлягеризация, шоуизация и эксгибиционизация в современной культуре. Горизонты культуры: от массовой до элитарной: Материаль IX ежегодной международной конференции 16-17 ноября 2007 г. Санкт-Петербург: Санкт-Петербургское философское общество, 2008. C. 15-21.

2. Афанасьєв Ю. Соціальне призначення мистецтва як системоутворювальний чинник національної художньої культури. Культурологічна думка. 2010. № 2. С. 169-173.

3. Бурдіна Е. О. Інфотейнмент як соціокомунікативне явище в сучасних українських інформаційно-публіцистичних телепроєктах: дис. ... канд. н. із соц. комунікацій: спец. 27.00 .04 «Теорія та історія журналістики». Харків, 2017. $257 \mathrm{c}$.

4. Гопко В. Так ли избыточно избыточное потребление? Гуманитарные исследования. 2014. № 3 (4). С. 13-15.

5. Дубовик Н. Шоутизация современной культуры. MICT: Мистецтво, історія, сучасність, теорія: зб. наук. пр. 2010. № 7. С. 224-233.

6. Ежов Д. А. Выборы в условиях шоуизации: технологии и социальные последствия. Вестник Института социологии. 2018. Т. 9. № 2 (25). С. 130-144.

7. Колтышева С. Я. Шоу-бизнес как сфера-магнит для религиозной метафоры. Вестник Южно-Уральского государственного университета. Серия: Лингвистика. 2008. № 16 (116). С. 83-88.

8. Коротаева И. В. Шоу-программы как феномен массовой культуры. URL: http:/elibrary.ru/download/27908761.htm

9. Мартынов В. Пестрые прутья Иакова: Частный взгляд на картину всеобщего праздника жизни. Москва: МГИУ, 2008. $140 \mathrm{c}$.

10. Романенко Ю. М. Шоуизация. URL: http:/hpsy.ru/public/ x3066.htm

11. Скрипка А. О. Шоу-технології як форма соціальної комунікації: автореф. дис. ... канд. соціологічних наук: спец. 22.00 .04 «Спеціальні та галузеві соціології». Харків, 2010. 19 c. 
12. Стаметов В. В. Природа шоу как массовой псевдокоммуникации: автореф. дис. ... канд. социол. н.: спец. 22.00.06 «Социология культуры, духовной жизни». Тамбов, 2008. $22 \mathrm{c}$.

13. Стаметов В. В. Шоу-технологии как фактор формирования тенденций отчужденности в обществе. URL: https://www.elibrary.ru/download/elibrary_15565251 44195992.pdf

14. Стаметов В. В. Шоу-феномен как форма массовой псевдокоммуникации. Вестник Тамбовского университета. Серия: Гуманитарные науки. 2008. № 10 С. $165-170$.

15. Тимохович А. Н. Социально-психологические факторы популярности шоу как массового зрелища: автореф. дис. ... канд. психол. н.: спец. 19.00.05 «Социальная психология». Москва, 2003. 20 с.

\section{References}

1. Akopyan, K. Z. (2008). Schlagerization, showization and exhibitionism in modern culture. Gorizonty kul'tury: ot massovoy do elitarnoy: Materialy IX yezhegodnoy mezhdunarodnoy konferentsii 16-17 noyabrya 2007 g. SanktPeterburg: Sankt-Peterburgskoye filosofskoye obshchestvo [in Russian].

2. Afanasyev, Yu. (2010). The social purpose of art as a systematic factor of national artistic culture. Kul'turolohichna dumka. Vol. 2 [in Ukrainian].

3. Burdina, E. O. (2017). Infotainment as a SocioCommunicative Phenomenon in Contemporary Ukrainian Information and Journalistic TV Projects: Candidate's thesis: 27.00.04. Kharkiv [in Ukrainian].

4. Gopko, V. (2014). Is it excessively excessive consumption? Gumanitarnyye issledovaniya. Vol. 3 (4) [in Russian].
5. Dubovik, N. (2010). Showcasing of modern culture. MIST: Mystetstvo, istoriya, suchasnist', teoriya: zb. nauk. pr. Vol. 7 [in Russian]

6. Yezhov, D. A. (2018). Elections in the conditions of showization: technologies and social consequences. Vestnik Instituta sotsiologii. Part 9. Vol. 2 (25) [in Russian].

7. Koltysheva, S. Ya. (2008). Show business as a spheremagnet for religious metaphor. Vestnik Yuzhno-Ural'skogo gosudarstvennogo universiteta. Seriya: Lingvistika. Vol. 16 (116) [in Russian].

8. Korotaeva, I. V. Show-programs as a phenomenon of mass culture. Retrieved from: http://elibrary.ru/ download/27908761.htm [in Russian].

9. Martynov, V. (2008). Motley rods of Jacob: A private look at the picture of the universal holiday of life. Moskva: MGIU [in Russian].

10. Romanenko, Yu. M. Showization. Retrieved from: http:// hpsy.ru/public/x3066.htm [in Russian].

11. Skrypka, A. O. (2010). Show technologies as a form of social communication: Extended abstract of candidate's thesis: 22.00.04. Kharkiv [in Ukrainian].

12. Stametov, V. V. (2008). Nature of the show as mass pseudocommunication: Extended abstract of candidate's thesis: 22.00.06. Tambov [in Russian].

13. Stametov, V. V. Show technologies as a factor in the formation of alienation trends in society. Retrieved from: https://www. elibrary.ru/download/elibrary_15565251_44195992.pdf [in Russian].

14. Stametov, V. V. (2008). Show-phenomenon as a form of mass pseudo-communication. Vestnik Tambovskogo universiteta. Seriya: Gumanitarnyye nauki. Vol. 10 [in Russian].

15. Timokhovich, A. N. (2003). Socio-psychological factors of the popularity of the show as a mass spectacle: Extended abstract of candidate's thesis: 19.00.05. Moskva [in Russian]. 